\title{
Customer value of smart metering: \\ Explorative evidence from a choice-based conjoint study in Switzerland
}

Simon Kaufmann, Karoline Künzel, Moritz Loock*

\author{
Simon Kaufmann \\ Repower AG \\ Talstrasse 10 \\ 7250 Klosters \\ Switzerland \\ simon.kaufmann@repower.com
}

Karoline Künzel

Good Energies Chair for Management of Renewable Energies

Institute for Economy and the Environment (IWÖ-HSG)

University of St.Gallen

$\mathrm{CH}-9000$ St. Gallen

Switzerland

karoline.kuenzel@unisg.ch

Moritz Loock*

Good Energies Chair for Management of Renewable Energies

Institute for Economy and the Environment (IWÖ-HSG)

University of St.Gallen

Tigerbergstr. 2

$\mathrm{CH}-9000$ St. Gallen

Switzerland

http://goodenergies.iwoe.unisg.ch

E-mail: Moritz.loock@unisg.ch

Tel.: +41712242586

fax: +41712242722

${ }^{*}$ corresponding author 


\begin{abstract}
Implementing smart metering is an important field for energy policy to successfully meet energy efficiency targets. From an integrated social acceptance and customerperceived value theory perspective we model the importance of customer value of smart metering in this regard. We further shape the model on a choice-based conjoint experiment with Swiss private electricity customers. The study finds that overall customers perceive a positive value from smart metering and are willing to pay for it. Further, based on a cluster analysis of customers' value perceptions, we identify four customer segments, each with a distinct value perception profile for smart metering. We find that energy policy and management should integrate a solid understanding of customer value for smart metering in their initiatives and consider different smart metering market segments within their measures.
\end{abstract}

Key words: smart metering, customer value, conjoint analysis, cluster analysis, energy policy 


\section{INTRODUCTION}

In a new proposal for an energy efficiency directive from June 2011, the EU renews the goal of reducing energy consumption by $20 \%$ by 2020 (COM/2011/0370, 2011). This has already been a key element of the Directive 2006/32/EC (Directive 2006/32/EC, 2006). In 2011 the EU points again to the importance of rolling-out smart meters but also states that failing to help end-users to save energy might be a major obstacle to mass-market diffusion (European Commission, 2011). This points to the importance of considering a customer value perspective when implementing smart metering. The importance of a customer value perspective is also evident in a statement of the European Smart Metering Alliances, which names customer acceptance as one of the main issues for smart metering: "Energy savings from smart metering and information feedback depends on acceptance and understanding by consumers of the basic premise. (...) Consumers should receive appropriate benefits from any cost reductions achieved by the Energy supply industry resulting from smart metering although this should not negate the financial drivers for the utilities" (ESMA, 2012). Despite being crucial for smart metering, research mostly focuses on engineering aspects of smart metering, and only a few studies point to customer needs (Forsa, 2010; Kranz et al., 2010; Giordano and Fulli, 2012). Furthermore, research from a customer perspective focuses mainly on the potential of reducing energy (and related costs) and on the effect of different energy tariffs (Faruqui et al., 2009; Stromback et al., 2011). However, smart metering offers all kinds of different services to customers and utilities alike. For example, a connected advanced metering infrastructure (AMI) allows for remote meter reading, accurate monthly billing, and enables demand response and load management (Leeds, 2009; Ryberg, 2010; Appelrath et al., 2012). Furthermore, if the smart meter is connected to the home area network, consumers can be provided with energy consumption feedback systems, with remote programming and steering services for appliances, with security services as well as with the possibility to manage decentralized energy feed-in from e.g., renewables or intelligent charging of plug-in electrical vehicles. For an overview about existing smart metering and smart grid technologies, providers of those technologies and resulting smart metering services we refer to the relevant literature (European Commission, 2005; European Commission, 2006; ESMA, 2008; SFOE, 2009; 2012; Leeds, 2009; Forsa, 2010; Ryberg 2010; Appelrath et al., 2012). 
Although a mandatory rollout of smart metering would foster the nationwide implementation of smart metering, it is unlikely to play a significant part in achieving a $20 \%$ reduction in energy consumption when it fails to incorporate the issue of consumer acceptance. First, an undifferentiated mandatory smart meter rollout might lead energy providers to either choose the cheapest smart metering solution or to implement smart metering services that provide value to the energy providers but not to the customer. Other services, which could provide value to the customer but are not perceived as highly profitable to the industry, might thus be disregarded (Marvin et al., 1999; Neenan and Hemphill, 2008; Darby, 2010). This could lead to suboptimal results because the lack of customer value prevents consumer acceptance of smart metering technologies. Customer value and consumer acceptance are crucial because only when customers perceive a value, they become interested in the technology and start using it (Davis, 1989; Kim et al., 2007) in their daily life, which in the case of smart metering - might ultimately result in a reduction of energy consumption (Marvin et al., 1999; Neenan and Hemphill, 2008; Honebein et al., 2009; Darby, 2010; Clastres, 2011; Giordano and Fulli, 2012). Second, even if policy makers oblige the industry to include certain services of value to customers into a mandatory smart metering solution, the results might still remain suboptimal with regard to the goal of reducing energy consumption by $20 \%$. It is likely that consumers' value perceptions of smart metering services - like for many other services - differ among various customer segments (DeSarbo et al., 2001; Ruiz et al., 2007; Wiedmann et al., 2009). Thus, even if this mandatory smart metering solution attracts some customers, it might fail to attract others (Darby, 2010). By ignoring the heterogeneous customer needs in the market, broad consumer acceptance of smart metering might not be achieved. Therefore, effective energy policy requires a sound understanding of different value perceptions of smart metering to design effective measures for smart meter implementation.

The study at hand intends to reveal the preferences of Swiss private energy consumers for smart metering services. The work is guided by the question, what is the perceived value of smart metering services for customers.

From an integrated social acceptance and customer value perspective we first model the importance of customer value of smart metering. We then test the model on a choice-based conjoint experiment with Swiss private electricity customers. The study finds that overall customers value smart metering and are willing to pay for it. Further, 
based on a cluster analysis of customer preferences, four segments were identified, each of which with distinct value perceptions of smart metering. We find that energy policy and management should integrate a solid understanding of customerperceived value for smart metering in their initiatives and consider the different market segments within their measures.

\section{THE ROLE OF CUSTOMER VALUE AND OF VALUE-BASED SEGMENTATION FOR IMPLEMENTING SMART METERING}

Our basic model (Figure 1) states that customer value is crucial for implementing smart metering. The model is derived from an integrated social acceptance and customer value perspective. The basic premise is that - as for all innovative energy technologies - social acceptance among various stakeholders is a precondition for the successful implementation and diffusion of smart meter technology and related services (Wüstenhagen et al., 2007; Wolsink, 2012). Among the most important stakeholders are customers (those who buy and/or use smart metering) and firms (those who develop and/or provide smart metering). A successful diffusion would require balancing the interest of those stakeholders in a pareto-efficient manner, so that all stakeholders maximize their value.

Whereas the company perspective is less critical, as firms usually are good in realizing their model, the customer value perspective is more crucial and has been approached by different research (Zeithaml, 1988; Sheth et al., 1991; Parasuraman, 1997; Slater, 1997; Woodruff, 1997; Holbrook, 1999; Belz and Bieger, 2006). According to Zeithaml (1988) and Sheth et al. (1991) consumers purchase a product or service if they perceive some kind of positive value. Zeithaml (1988) defines perceived value of a product or service as an overall assessment by the customer of what is given (drawbacks) and what is received (benefits). It is important to note that according to this definition value is not objective or simply given, but rather it is based on an individual perception. Regarding smart metering this means that the customerperceived benefits of smart metering must exceed the perceived drawbacks. Only then will the customer accept, be willing to pay for and use smart metering services. Meaning, only then will there be a market acceptance of smart metering by consumers, which is a part of social acceptance (Wüstenhagen et al., 2007; Wolsink, 2012). In order to ensure market acceptance of smart metering by firms - another part of overall social acceptance (Wüstenhagen et al., 2007; Wolsink, 2012) - firms must receive some kind of revenue in exchange for developing and providing smart 
metering services, e.g., via the price the customers pay for these services. From the company perspective the price is important to notify and satisfy the firm's value on smart metering. From the customer perspective, however, the price consists of a drawback and thus reduces the overall customer-perceived value (Zeithaml, 1988). The spotted arrow with the dollar sign in Figure 1 demonstrates this relationship. When deciding on which smart metering services to offer and how to price them, two things are of critical importance. First, one should have a thorough understanding of which smart metering services provide benefits to the customers. Only those services would be able to compensate for the perceived drawback of the prices because they offer enough benefit in exchange and thus elicit a willingness-to-pay (Zeithaml, 1988). Second, price setting for a service should be based on an assessment of customers' willingness-to-pay instead of a cost plus approach to ensure that the overall customer-perceived value (now also including the price) of the respective service is positive and thus leads to customer acceptance and purchase.

Following the concept of customer value and social acceptance, the customerperceived benefits of smart metering should exceed the perceived drawbacks in order to ensure market acceptance and diffusion of smart metering. Previous research claims that customer-perceived benefits indeed exceed the perceived drawbacks (Forsa, 2010; Curtius et al., 2012). Thus, we assume:

Assumption 1a: Customers are willing to pay for smart metering.

Assumption 1b: The positive customer-perceived value of smart metering will in turn result in purchase and in market acceptance of smart metering by consumers - a part of social acceptance.

Furthermore, as smart metering can provide a variety of services, which offer different benefits, one can assume that customers' willingness-to-pay differs for different services and service combinations.

Assumption 2: Different smart metering services result in different perceived benefits and thus the customers' willingness-to-pay differs for different smart metering services and bundles of services. 
Literature on customer value also suggests that different customers have different needs and therefore a market segmentation based on the heterogeneity of value perceptions in a market is needed (Kotler, 1997; DeSarbo et al., 2001; Dibb et al., 2002; Morris et al., 2005; Ruiz et al., 2007; Wiedmann et al., 2009). DeSarbo et al. (2001) state that "there are indeed heterogeneous interpretations of customerperceived value, and multiple customer segments may assign differential importance weights to the value drivers" (p. 846). Thus, an assessment of customer value on an aggregate level might be misleading (DeSarbo et al., 2001; Ruiz et al., 2007; Wiedmann et al., 2009). This presumably will hold in the case of smart metering, which may not be valued by all customers in the same manner. For instance, technology-oriented value propositions like coupling smart metering with mobile devices like iPhones might be very valuable for customers who favor smart phones. However, other customers with less technological exposure may not be attracted by such value propositions (Darby, 2010). Interestingly, we find that up to now discussions on smart metering have been dominated by an engineering or technological perspective. These discussions are less open to other (maybe even larger) segments, which need to be attracted in a different way. Thus, a value-based segmentation of the market for smart metering is crucial to better account for the heterogeneity of value perceptions in that market.

Assumption 3: Different customer segments value smart metering differently.

Figure 1 displays the simplified model derived from the aforementioned theoretical background and sets the concept of customer value for smart metering in context. 


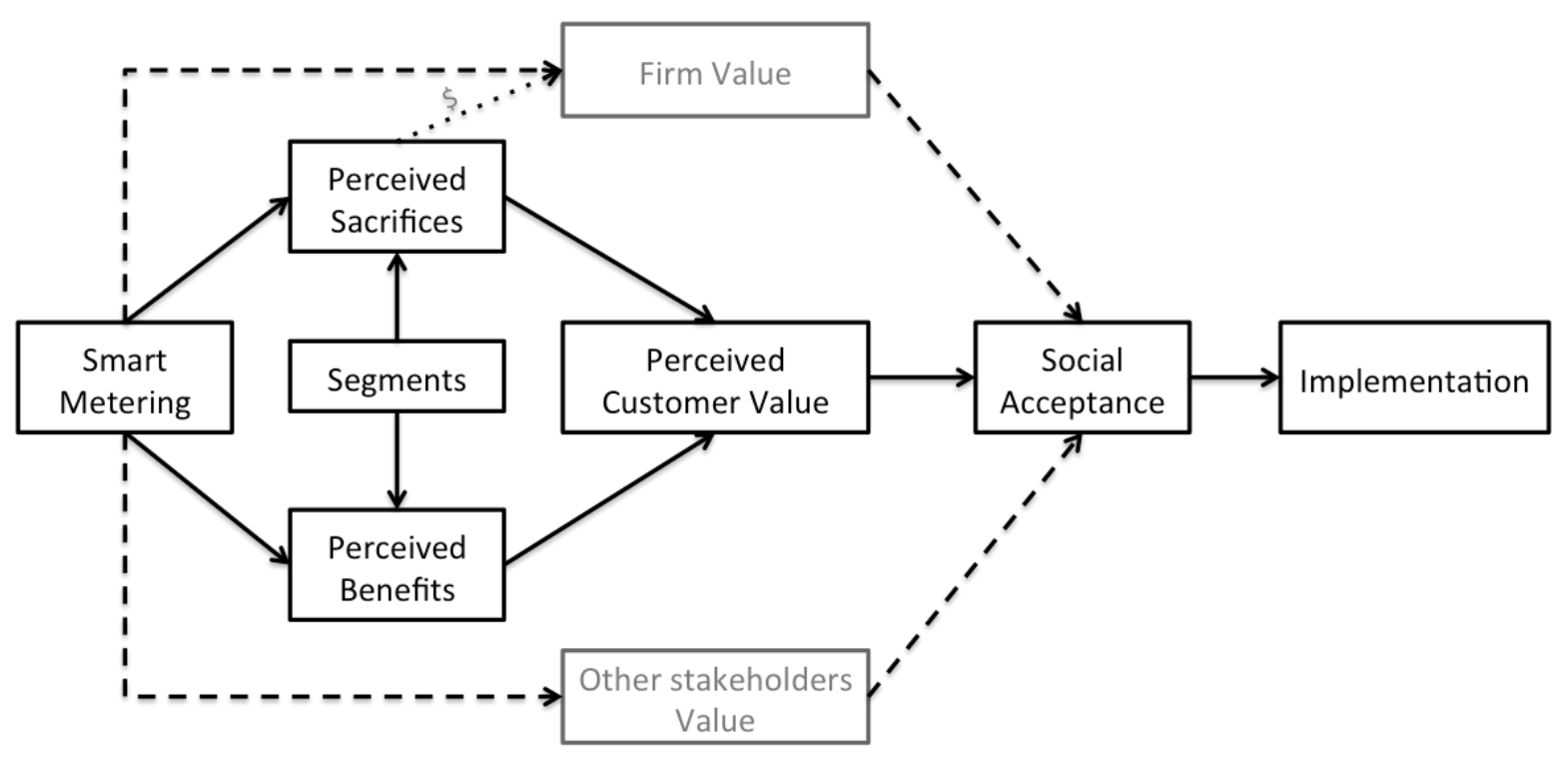

Fig. 1. Customer value of smart metering

\section{METHOD}

\subsection{Focus on the Swiss market}

When elaborating on customer perceived value of smart metering a focus on one national market is important, as different legislative aspects and different national industry stages are hardly comparable and would lead to data biases.

In this study we focus on the Swiss market, a market where energy policy to date has not been a driving force of implementing smart metering. However, it is reasonable to presume that smart metering is going to be important for Swiss firms and policy makers in future. On the one hand, energy efficiency is one of four essential building blocks that have been defined by the Swiss government to secure energy supply and meet climate policy goals (SFOE, 2011; Schweizerischer Bundesrat, 2011) and smart metering can contribute to these goals of the Swiss government (SFOE, 2009). On the other hand, in 2012 the SFOE published an impact assessment, which shows the feasibility and benefits of large-scale implementation of smart metering in Switzerland (SFOE, 2012). Based on that assessment we expect Switzerland to prepare a smart metering rollout in the future. However, as for today, a general national policy approach on smart metering, such as a mandatory smart metering rollout like for example in Sweden, is missing (SFOE, 2012). The lack of such a mandatory smart meter rollout in Switzerland makes it possible to study customers' value perceptions of and willingness-to-pay for smart metering without potential 
biases that result from energy policy measures aimed at the diffusion of smart metering. For example, customers might be more likely to thoroughly examine the value of smart metering when they decide voluntary on the installation of a smart meter in their home instead of being forced to do so by legislation. Thus, - besides being ideal from a point of view of conducting economic research - we consider Switzerland as an ideal country for our study.

\subsection{Survey and sample}

We decided to focus on one of the potential pilot projects for smart metering; in this case it was a project by the electricity utility in Davos (EWD). The customers of EWD were not yet equipped with smart meters and our study was aimed at providing EWD with insights on which smart metering services to include in their pilot. Therefore, we needed to ensure the same level of knowledge about smart metering among the participants. Thus, we provided basic information about smart metering and also clarified that different tariffs could impact customers' energy costs both positively and negatively in the survey introduction. The survey was first pretested with 10 people not necessarily familiar with smart metering and one expert from the EWD and then was available online from August 5-30, 2010. The sample was generated as a convenience sample among private customers of the EWD (Weiers, 2005; Orme, 2006). The invitation to the survey was distributed via different channels. The EWD provided a link on their homepage and distributed flyers at their point of sales. Further, all employees with direct customer contact were advised to inform the customers about the survey. Additionally, the invitation was send to different associations and a residential building cooperative. Within three weeks 144 responses could be collected. Twenty three responses had to be discarded, as they were neither from customers of the EWD nor from decision-makers within their household. Additionally, 34 responses were not complete, so that a total of 87 valid responses remained for the analysis. With that the minimum number for conjoint analysis with approximately 30 is fulfilled (Schaich, 1990; Schira, 2005). As agreed with the EWD the survey did not collect socio-demographic data.

\subsection{Choice-based conjoint experiment and analysis}

To investigate customers' value perceptions of smart metering we conducted a choice-based conjoint experiment. Choice-based conjoint analysis is a well- 
established method in marketing research to measure customer preferences. It is beyond the scope of the paper to discuss the fundamentals of the method in detail, so we refer to relevant literature here (Louviere et al., 2003; Train, 2003; Gustafsson et al., 2007; Orme, 2010). Furthermore, research has utilized conjoint analysis in the discourse on clean energy, energy-efficiency and energy policy (Sammer and Wüstenhagen, 2006; Burkhalter et al., 2009; Loock, 2012). The conjoint approach builds on the basic premise that customer preferences sum up part worth (Backhaus et al., 2008). In accordance, customer value of smart metering would not come from a single attribute but a conjoint evaluation of different attributes. The conjoint analysis decomposes attribute packages and calculates the single value of product and service attributes, which are shown as part-worth utilities (Backhaus et al., 2008). To design the choice experiment, collect and analyze the data we used Sawtooth Software ${ }^{1}$.

In order to conduct a conjoint analysis, it is essential to derive a list of relevant attributes and levels that capture smart metering from a customer's point of view. We derived the list based on preliminary research (semi-structured interviews with experts and desk research). Table 1 shows the attributes and levels for our study.

\section{Table 1}

Attributes and levels for choice-based conjoint experiment

\begin{tabular}{|c|c|}
\hline Attribute & Levels \\
\hline \multirow{3}{*}{ Tariff (low/high) } & $11 / 17$ Rp. per kWh \\
\hline & 8 / 30 Rp. per kWh \\
\hline & 6 / 50 Rp. per kWh \\
\hline \multirow[t]{3}{*}{ Base fee per month } & CHF 23.00 \\
\hline & CHF $23.00+$ CHF 2.00 \\
\hline & CHF $23.00+$ CHF 4.00 \\
\hline \multirow{2}{*}{ Remote meter reading with accurate monthly billing } & Yes, included in the package \\
\hline & No, not included in the package \\
\hline \multirow[t]{4}{*}{ Real-time consumption feedback } & Yes, via in-home display \\
\hline & Yes, via online web portal \\
\hline & Yes, via mobile device \\
\hline & No, not included in the package \\
\hline \multirow[t]{2}{*}{ Programming and steering services } & Yes, included in the package \\
\hline & No, not included in the package \\
\hline \multirow{2}{*}{$\begin{array}{l}\text { Home security and surveillance services with alert } \\
\text { functions }\end{array}$} & Yes, included in the package \\
\hline & No, not included in the package \\
\hline
\end{tabular}

The first attribute is the tariff model. We chose a critical peak price (CPP) model over a time of use (TOU) model. We are aware of differences of the impact of CPP and TOU (see e.g., Faruqui and Sergici, 2010) and suggest that future work considers 
differences of fit between both models and different customer segments. For our study we chose the CPP because CPP has been proven to have a higher impact on peak demand reduction (Faruqui et al., 2001; Faruqui and Mauldin, 2002; Herter, 2007; Faruqui et al., 2010; Faruqui and Sergici, 2010) and thus might have a higher value to customers by enabling a significant reduction of their electricity bills. Furthermore, CPP better accounts for the specifics within our sample region and is better related to the pricing structure of the EWD. Our basic model relates to the EWD tariff "EWD Doppel" and the "consumption category H4". This category equals the average Swiss household with an average annual consumption of approximately $4500 \mathrm{~kW} \mathrm{~h}$ (Elcom, 2010). For the average EWD customer approximately one third of the energy costs are fixed costs and are paid in a monthly fee. The Swiss national average costs are $21.3 \mathrm{Rp} . / \mathrm{kW}$ h. Without fix costs this results in the tariff which we incorporate as our basic level with $11 \mathrm{Rp} . / \mathrm{kW} \mathrm{h}$ as a low tariff and $17 \mathrm{Rp} . / \mathrm{kW} \mathrm{h}$ as a high tariff of the actual tariff structure (EWD, 2010). Within the expert interviews of our preliminary research we learned that a factor of 1.5 as a span between low and high price tariff is too low to attract customers to consume energy more flexible and to shift loads. This is even more problematic as energy costs only account for a small portion of household expenditure in Switzerland (Braunwalder, 2007). So the following models have a greater price span and thus higher saving potentials as well as a higher risk exposure to high tariffs. The second attribute is the base fee, which is the price attribute in our experiment. Here again the first level is the real base fee for EWD customers, which was 23.70 CHF per month in 2010 when the survey was carried out (EWD, 2010). The following two levels have a step-wise higher base fee $(+2 \mathrm{CHF}$ and $+4 \mathrm{CHF})$. We used this step-wise higher base fee for research purpose because this allows us to measure the willingness-to-pay for smart metering and to assign a monetary value to the single attributes and their levels within the further conjoint analysis. The third attribute covers remote meter reading with accurate monthly billing. Either it is included in the package or not. The fourth attribute consists of the possibility of real-time consumption feedback, which is either not included in the package or included and transmitted on different devices, such as on an in-home display, online web portal or mobile phone. The fifth attribute proposes programming and steering services of single devices and the last attribute consists of home security and surveillance services with alert functions. For both attributes the services are either included in the package or not. 


\section{RESULTS AND ANALYSIS}

\subsection{Sensitivity analyses and market share}

To reveal which attributes and levels are of which value to customers, we calculate the part-worth utilities ${ }^{2}$ by Hierarchical Bayes as provided in the Sawtooth software package (see appendix). Hierarchical Bayes produces statistically accurate results because the calculation of part-worth utilities is based on the preferences of individual respondents (Sawtooth Software, 2009). To interpret the part-worth utilities we conducted a sensitivity analysis based on share of preferences. This analysis allows us to estimate the value of each service level by its influence on change of the market share. This is done by changing one attribute level of one of two products whereas all other levels remain the same for both products. Thus, an increase or decrease in value is a result of changing a level of an attribute to another. The results of the sensitivity analysis are reported in Figure 2.
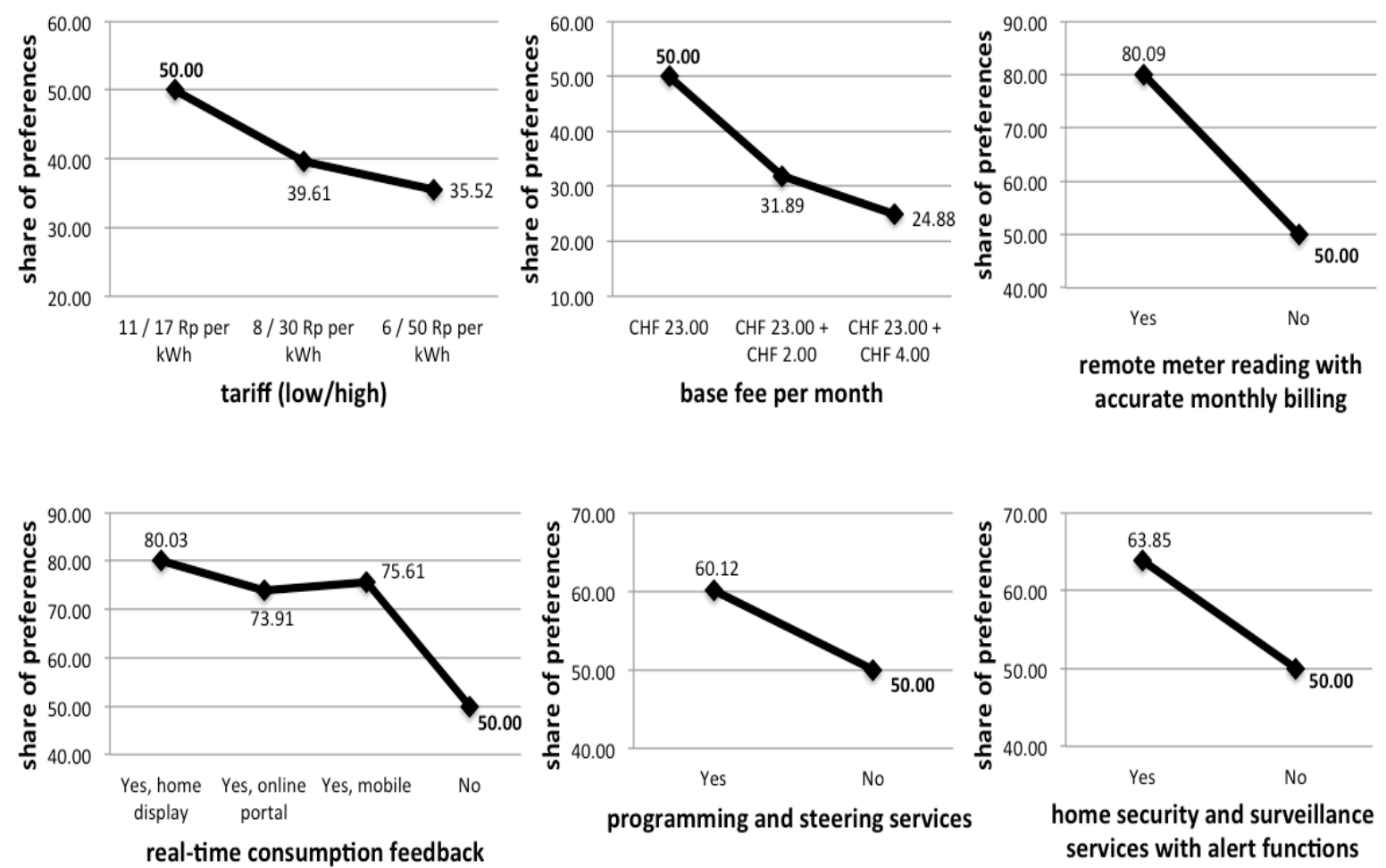

Fig. 2. Sensitivity analysis based on share of preferences

The analysis reveals that, for example, a visualization of the energy consumption by an in-home display has the highest customer-perceived value compared to the other levels of this attribute. If the market consists of only two products, each providing the same level of services (highlighted by the bold numbers of 50.00 in Figure 2), 
providing the service of visualization of the energy consumption by an in-home display in one of the two offerings results in a change of market preferences of $30.03 \%$ for the respective offering (80.03-50.00).

Based on the results in figure 2, one can assume that the ideal market offering would consist of an offering with service levels resulting in the highest market share. However, this conclusion does not account for the heterogeneity in the market and thus might fail to capture the whole market potential (DeSarbo et al., 2001).

\subsection{Willingness-to-pay}

By calculating the willingness-to-pay it becomes possible to quantify the values of the conjoint analysis in terms of monetary value (Green and Srinivasan, 1990; Sammer and Wüstenhagen, 2006; Orme, 2010) ${ }^{3}$. The willingness-to-pay can be determined as follows:

$$
\text { willingness }- \text { to }- \text { pay }_{i}=\frac{N_{i} \times \Delta \operatorname{Pr} \text { ice }}{\operatorname{Max} N_{\operatorname{Pr} i c e}}
$$

$\mathrm{N}_{\mathrm{i}}$ is the part-worth value of an attribute $\mathrm{i}, \Delta$ price is the difference between the highest and lowest level of the price attribute base fee (CHF $23+$ CHF $4-$ CHF $23=$ $\mathrm{CHF}$ 4.00). MaxN $\mathrm{N}_{\text {price }}$ equals the maximum value of the attribute price $(0.91+0.72=1.63)$ (Green and Srinivasan, 1990; Sammer and Wüstenhagen, 2006; Orme, 2010). Figure 3 displays the values. A value higher than zero indicates the willingness-to-pay a premium, whereas a negative value would require a discount on a given price. 

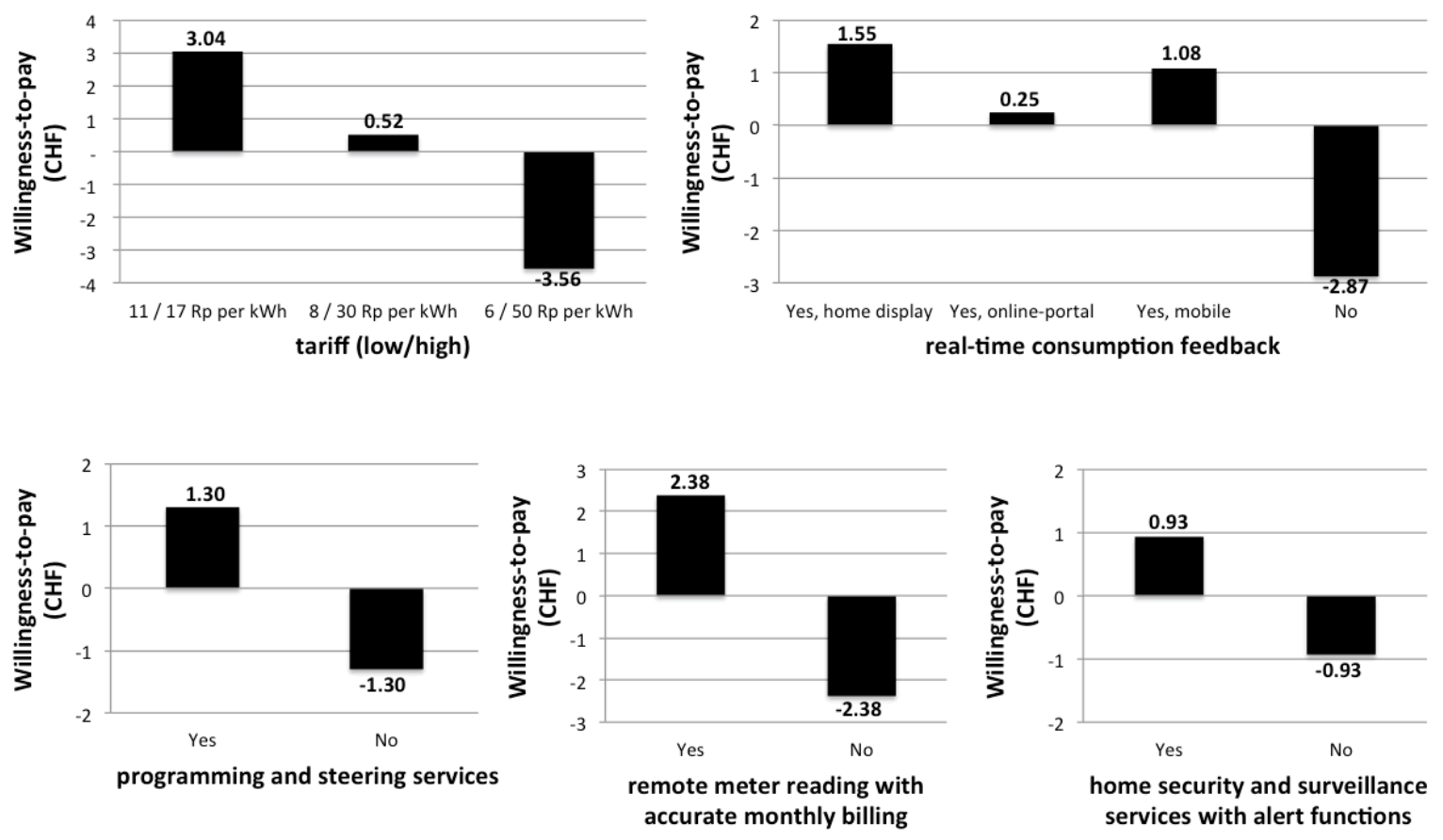

Fig. 3. Willingness-to-pay

Within the experiment customers would be willing to pay a premium of up to $9 \mathrm{CHF}$ to get their most desired smart metering product $(3.04+1.55+1.30+2.38+0.93)$. However, customers would also demand a discount of the same value if their smart metering product did not fit their needs. The results of our willingness-to-pay calculation for the different tariffs indicate that consumers are willing to pay more (3.04 CHF for a tariff of $11 / 17 \mathrm{Rp} . / \mathrm{kW} \mathrm{h}$ ) to get the tariff model with the lowest risk or they would expect a discount of $3.56 \mathrm{CHF}$ when forced to accept the highest offered tariff model. A possible interpretation is that they are willing to pay to avoid the risk related to high tariffs (Chapman et al., 2001; Faruqui and Mauldin, 2002; Herter, 2007; Faruqui et al., 2010). The related chance of falling into the lowest tariff seems either to be unsuitable to balance this risk or seems not to have been realized by respondents.

To compare the costs of smart metering with the willingness-to-pay we could calculate how long it takes for the costs to be amortized. In the recent published impact assessment of smart metering in Switzerland (SFOE, 2012) five scenarios for smart meter implementation and related costs were reported. The scenarios range from "status quo", which does not foresee the implementation of smart meters and which uses the existing infrastructure, to the scenario "nationwide implementation +", which consists of an implementation of smart meters at $97 \%$ of the metering points 
until 2035, a smart meter enabling infrastructure, dynamic tariffs, data collection in a 15 min. interval as well as load management for various appliances. The scenario "nationwide implementation +" allows for all of our services to be offered. Whereas the total accumulated costs between 2015 and 2035 of the scenario "status quo" would amount to 4319 million $\mathrm{CHF}$, those of the scenario "nationwide implementation +" would amount to 5236 million CHF (SFOE, 2012). The costs include investment, operating, communication costs and costs for business processes (SFOE, 2012). For a detailed overview of the costs and related parameters we refer here to the impact assessment (SFOE, 2012). If we subtract the total accumulated costs of the scenario "status quo" from those of the scenario "nationwide implementation +" we arrive at the added costs due to the implementation of smart metering, which amount to 917 million CHF.

Today 4.9 million meters are installed in Switzerland (SFOE, 2012). If each of the households and companies who are equipped with these meters would pay $9 \mathrm{CHF}$ per month for their ideal smart metering offering, this would amount to a revenue of 529.2 million CHF per year. Bringing this into relation with the additional costs for smart metering of the "nationwide implementation +" scenario, 917 million CHF, this would mean that these costs could, for example, be amortized in approximately 2-3 years ${ }^{4}$.

\subsection{Cluster segments for smart metering}

To understand whether and how customer preferences for smart metering differ within different customer segments, we run an agglomerative hierarchical cluster analysis (Backhaus et al., 2008; Berekoven et al., 2009) based on the individual partworth utilities with SPSS. The distance was measured as in most studies by squared Euclidean distance, which indicates how similar or non-similar the objects are considering the attributes (Brosius, 2008). We used the Ward method as algorithms. For validation we compared the results with different other algorithms and considered three further criteria (Backhaus et al., 2008): First, the Elbow-criterion, which over a long time showed a low failure and only strongly increased within the last steps (see appendix). Our interpretation is that this suggests a lower number of clusters to be appropriate. Second, we tested the significance of the distinctiveness among the clusters as proposed by Backhaus et al. (2008), based on the following model: $F(A G)=$ variance of attribute $A$ in group $G /$ variance of attributes $A$ within the whole 
sample. Thereby a cluster is homogenous if $F(A, G)<1$ for all $A$ (Backhaus et al., 2008) (see appendix). The determination of four as the final number of clusters was based on these two criteria. We thereby needed to exclude one non-fitting object to ensure homogeneity for cluster three, which however is feasible as reported by Punj \& Stewart (1983). Finally, as a third criterion, we assessed the clusters from a qualitative perspective to determine whether they appear consistent from a content perspective to derive implications for energy policy, management and research.

Figure 4 illustrates the resulting clusters by highlighting the biggest differences in the respective part-worth utilities among the clusters (see appendix for all part-worth utilities). The dotted line represents the total part-worth utilities for the whole sample to illustrate how the value perceptions of each cluster differ from those of an aggregate assessment of customer value.

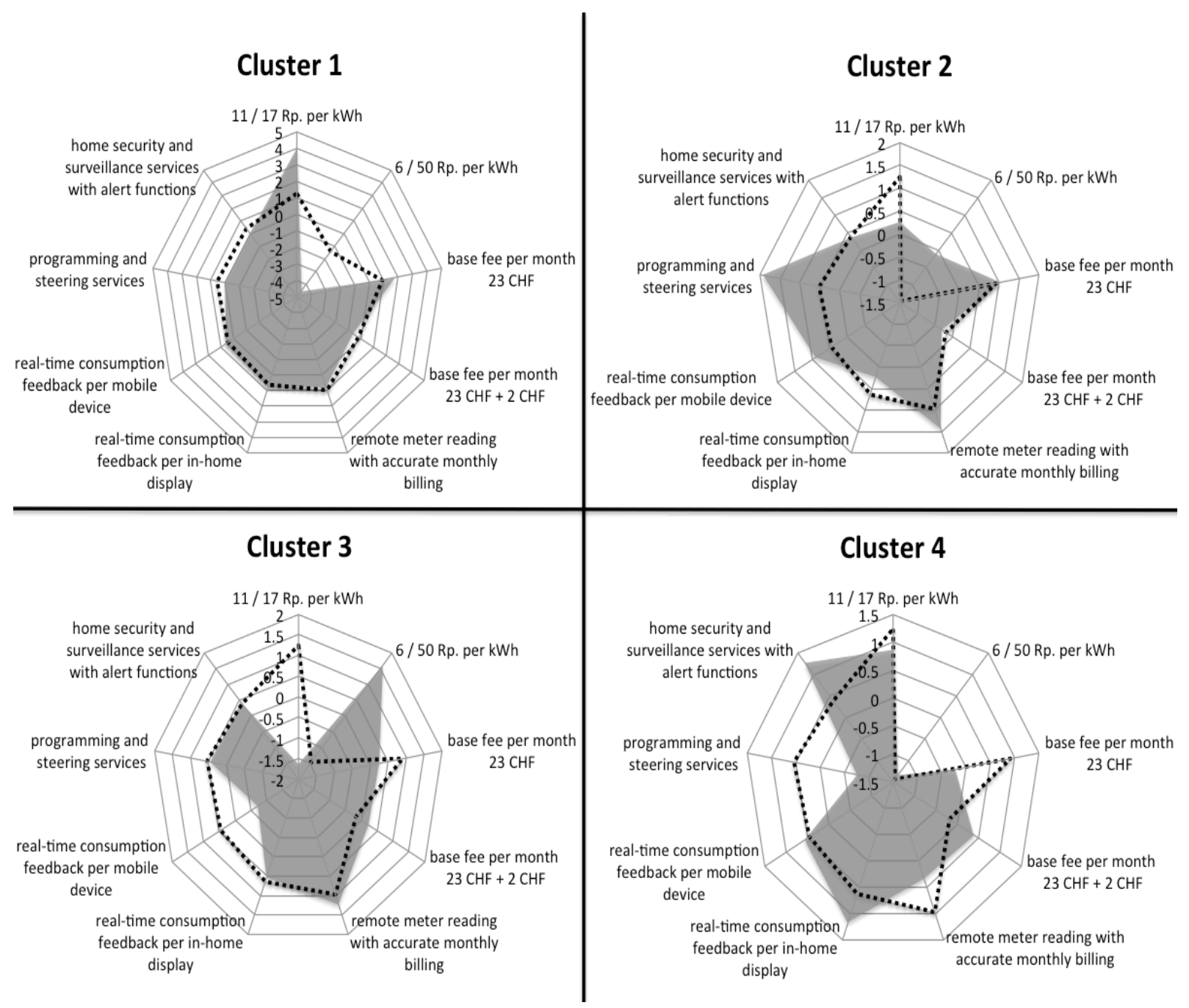

Fig. 4. Customer segments for smart metering 
The first cluster (39\% of the customers) can be named "risk-averse". The strong preference for the lowest tariff model with low risk is the dominating characteristic. Apparently, customers of the first cluster do not see the benefit of potentially lower electricity bills due to dynamic pricing programs such as CPP (Faruqui et al., 2010). One explanation could be that they have difficulties in estimating their ability to react to the prices through energy efficiency measures and thus are more worried about the risk of an increase in their bills rather than focusing on the potential savings (Faruqui and Mauldin, 2002; Faruqui et al., 2010). Thus, this group might not be the ideal target group for dynamic pricing programs unless these provide a risk hedging possibility (Chapman et al. 2001; Faruqui and Mauldin, 2002). Also customers within this segment do not seem to be willing to pay ${ }^{5}$ a higher base fee reflected by their stronger preference for the lowest base fee compared to other clusters and the total sample. Furthermore, it appears that services related to programming and steering and home security do not provide as much value to customers within this segment as to customers of other segments. As for energy consumption feedback and remote meter reading this segment's value perception is approximately as high as the aggregated value perception of the total sample. Overall, this segment might be attracted by basic, low risk smart metering services, including energy consumption visualization and remote meter reading. The price for those additional services needs to be clearly attributed to the added services and separated from base fee.

The second cluster ( $29 \%$ of the customers) can be named "technology minded". It is dominated by high preferences for steering and programming services. Additionally, customers within this segment perceive a higher value from visualization via mobile devices (0.9) and remote meter reading with accurate monthly billing (1.44) compared to the total sample and other segments. Furthermore, the perceived value of the lowest tariff model is below that of the total sample and customers within this segment do not seem to perceive such a high risk with a higher tariff model compared to cluster one and four. This indicates that customers within this segment might be more inclined to participate in dynamic pricing programs and demand response. Finally, customers of this segment again prefer the lowest base fee. Thus, the ideal offering of smart metering for this segment should consist of a standard base fee and additional services such as programming and steering with a high customer-perceived benefit should be priced separately to capture the higher willingness-to-pay for such services within this segment. 
The third cluster $(20 \%$ of the customers) can be named "price sensitive". The most visible characteristic is the high value customers assign to the tariff model providing the lowest tariff $(6 / 50 \mathrm{Rp} . / \mathrm{kW} \mathrm{h})$. Although this tariff is also associated with a comparably high risk, customers within this segment seem to value the option to save on the low price tariff. Thus, this segment seems to be the ideal target group for dynamic pricing programs such as CPP. Going along with the preference for the highest tariff model is that the detailed monthly invoice is perceived as valuable by this segment. Furthermore, customers within this segment do not seem to attribute such a high value to a low base fee as the previous clusters, indicating that the base fee for this cluster is less important and could thus be augmented. Overall, customers within this segment seem to be ready to actively manage and control their energy behavior to leverage low-price tariffs. Thus, a smart meter offering enabling them to do so, e.g., dynamic pricing and services to enable demand response, might be ideal.

The fourth cluster (17\% of the customers) can be named "safety-oriented". An important characteristic is the strong preference for home security services compared to other clusters and the total sample. Additionally, customers within this segment attribute the highest value to energy consumption visualization via in-home display. Interestingly, at the same time, customers within this segment do not attribute a higher value to high tariff models. This might be an indicator that being able to react to dynamic prices with the help of energy consumption visualization might not be the only value of visualization tools. For example, it might be possible that energy consumption visualization provides value to customers by ensuring security at home (e.g., detecting malfunctioning devises with the help of visualization tools). Of further notice is that this is the only segment, which attributes a higher value to a higher base fee. Additionally, customers of this segment do not seem to be that much interested in programming and steering services and attribute a fairly small value to remote meter reading with accurate billing. Thus, an ideal smart metering offering for this segment would focus on value associated with home security services, including in-home displays with detailed consumption feedback for single devices. If remote meter reading needs to be included in the offering for allowing energy consumption feedback, it should not be priced due to the relatively small customer-perceived value. Instead the costs could be amortized through the possibility of a higher base fee in this segment. 


\section{CONCLUSION AND IMPLICATIONS FOR ENERGY POLICY}

The study reveals preferences of Swiss private energy consumers for smart metering services. From an integrated social acceptance and costumer value perspective we first model the importance of customer value of smart metering. We then further verify the model with a choice-based conjoint experiment with Swiss private electricity customers. The study finds that, overall, customers value smart metering and are even willing to pay for it and thus there is potential for amortizing the costs of a smart meter implementation. Furthermore, we found that different customer segments exist ("risk-averse", "technology minded", "price sensitive", "safetyoriented") and that the value perceptions differ substantially among those segments. Thus, a standard smart metering offering for the whole market might lead to suboptimal results as it fails to address the heterogeneity in value perceptions and thus potential differences in willingness-to-pay.

Based on a value-based segmentation done by a cluster analysis of customer preferences we conclude that there are four different service bundles, which correspond in an optimal manner to the individual customer segments' value perceptions. These bundles are displayed in table 2.

\section{Table 2}

Service bundles for different segments

\begin{tabular}{|c|c|c|c|c|}
\hline Attribute & $\begin{array}{c}\text { Cluster } 1 \\
\text { Risk-averse }\end{array}$ & $\begin{array}{c}\text { Cluster } 2 \\
\text { Technology } \\
\text { minded }\end{array}$ & $\begin{array}{c}\text { Cluster } 3 \\
\text { Price } \\
\text { sensitive }\end{array}$ & $\begin{array}{c}\text { Cluster } 4 \\
\text { Safety- } \\
\text { oriented }\end{array}$ \\
\hline Tariff (low/high) & $\begin{array}{l}11 / 17 \mathrm{Rp} . \\
\text { per kWh }\end{array}$ & $\begin{array}{l}11 / 17 \text { or } \\
6 \text { / } 50 \mathrm{Rp} . \\
\text { per kWh }\end{array}$ & $\begin{array}{l}6 / 50 \mathrm{Rp} . \\
\text { per kWh }\end{array}$ & $\begin{array}{l}11 / 17 \mathrm{Rp} . \\
\text { per kWh }\end{array}$ \\
\hline Base fee per month & CHF 23.00 & CHF 23.00 & $\begin{array}{l}\text { CHF } 23.00 \\
\text { or } \\
\text { CHF } 23.00+ \\
\text { CHF } 2.00 \\
\end{array}$ & $\begin{array}{l}\text { CHF } 23.00+ \\
\text { CHF } 2.00\end{array}$ \\
\hline $\begin{array}{l}\text { Remote meter reading with accurate } \\
\text { monthly billing }\end{array}$ & $\checkmark$ & $\checkmark$ & $\checkmark$ & $\checkmark$ \\
\hline $\begin{aligned} & \text { Real-time consumption feedback via } \\
&- \text { in-home display } \\
&- \text { online web portal } \\
&- \text { mobile device }\end{aligned}$ & $\begin{array}{l}5 \\
x \\
x\end{array}$ & $\begin{array}{l}x \\
x \\
\checkmark\end{array}$ & $\begin{array}{l}x \\
x \\
x\end{array}$ & $\begin{array}{l}5 \\
x \\
x\end{array}$ \\
\hline Programming and steering services & $x$ & $\checkmark$ & $\checkmark$ & $x$ \\
\hline $\begin{array}{l}\text { Home security and surveillance } \\
\text { services with alert functions }\end{array}$ & $x$ & $\checkmark$ & $\checkmark$ & $\checkmark$ \\
\hline
\end{tabular}


Besides a distinct communication and marketing approach for each of the segments and the respective service bundles, there are other building blocks for a successful implementation.

In general, given the relevance of a customer value perspective for smart metering, we find that energy policy makers should integrate a solid understanding of customer-perceived value of smart metering in their initiatives and measures. For managers it will be important to monitor the customer-perceived value for smart metering and innovate services that might be able to deliver a value to customers. Additionally policy makers as well as managers should consider the different market segments, as each segment might need to be attracted differently in order to foster smart metering implementation and acceptance of the technology.

In particular, we consider it important to differentiate a potential mandatory smart metering rollout. As discussed in the introduction, a mandatory smart metering rollout might lead to suboptimal results because either firms might choose smart metering solutions with benefits for the industry but not for the customer (Marvin et al., 1999; Neenan and Hemphill, 2008; Darby, 2010), or the solutions might only attract some customers but not all (Darby, 2010). We recommend designing energy policies along different customer segments (or at least to consider these different segments). Energy policy could, for example, encourage firms to implement different customeroriented solutions by providing some kind of incentives, such as tax reductions for firms, which develop different customer-oriented solutions and thus engage a broad customer base in smart metering. Therefore, policy measures for smart metering should include a result-oriented (engagement of customer) aspect. Our results also shed light upon how to approach the introduction of dynamic pricing programs such as CPP and demand response, which both can be beneficial for customers (lower bills) as well as utilities (load shifting and grid stability) (Herter, 2007; Faruqui et al., 2010; Faruqui and Sergici, 2010). Certain customer segments ("price-sensitive", maybe "technology minded") either attribute a high value to tariff models with a broad span of high and low tariffs or do not perceive a high risk of such tariff models. These customer groups should be the first target groups when introducing dynamic pricing or demand response because little effort is needed to convince them about the benefits. However, our results also show that certain customer segments ("riskaverse") would rather avoid dynamic tariffs due to the perceived risk of an increase in their bills (Faruqui et al., 2010). To overcome this initial customer inertia, managers 
or policy makers could offer some risk mitigation features, such as a "get-out-of-jailcard" or setting an upper limit on the number of high-priced hours (Chapman et al., 2001; Faruqui and Mauldin, 2002). Furthermore, customer education, providing the right technology and a simple and transparent design are key to foster adoptions of such programs (Faruqui and Mauldin, 2002). Finally, energy policy should keep in mind that customers not only differ according to their value perceptions of smart metering but also according to their resources. Thus, policy makers should consider some mechanism, like special loan programs, to ensure that e.g., fuel poor households with low income can also adapt smart metering services and dynamic prices and thus profit from the potential benefits (e.g., better feedback on consumption and therefore potentially lower bills) (Darby, 2011).

\section{LIMITATIONS AND RESEARCH OUTLOOK}

Our study is of explorative nature only and our sample approach comprises some biases. Although our sample was a convenient sample and thus may not lead to a fully representative sample, the approach is common practice and can be justified from the point of view of conducting economic research (Orme, 2006; Weiers, 2005). Furthermore, we were not able to collect socio-demographic data, which further limits the representativeness of our results. We tried to overcome this shortcoming by distributing the survey through different channels. Due to the lack of sociodemographic data we further could not characterize the different segments found in our study. Thus, it will be important in a next step to gain larger datasets and even conduct cross-country studies for customer preferences of smart metering. Such studies should also incorporate socio- and psycho-demographic criteria to further sharpen our understanding of customer segments and they should measure the impact of different legislative aspects on customer value. Additionally, it would be of interest to conduct a different experimental setup, which allows us to observe actual behavior (rather than an online-based experiment only). Such research would allow us to validate the willingness-to-pay further and compare the conjoint results with additional data (e.g., by the BDM-method as proposed by Wertenbroch and Skiera, 2002; Miller et al., 2011). Furthermore, other segmentation approaches, such as the finite-mixture methodology (DeSarbo et al., 2001) could be used to validate our findings. Also of interest would be to investigate which tariff leads to what change in preferences and whether different pricing models (e.g., TOU) or the introduction of 
demand response would change our findings on customer-perceived value and willingness-to-pay. Finally, there is need for research that elaborates on customerperceived value in context and investigates how customer-perceived value of smart metering can be aligned with a firm value perspective and, for instance, how it could be transferred to actual business models. 


\section{REFERENCES}

Appelrath, H.J., Kagermann, H., Mayer C. (Eds.), 2012. Future Energy Grid. Migrationspfade ins Internet der Energie. Acatech Studie Februar 2012. Retrieved 20 August 2012 from <http://www.acatech.de/fileadmin/user_upload/Baumstruktur_nach_Website/Acatech/root/de/Publ ikationen/Projektberichte/acatech_STUDIE_Future-Energy-Grid_120131_WEB_final.pdf>

Backhaus, K., Erichson, B., Plinke, W., Weiber, R., 2008. Multivariate Analysemethoden: Eine anwendungsorientiere Einführung (12th ed.). Springer Verlag, Berlin.

Belz, C., Bieger, T., 2006. Customer Value: Kundenvorteile schaffen Unternehmensvorteil. miFachverlag, München.

Berekoven, L., Eckert, W., Ellenrieder, P., 2009. Marktforschung: Methodische Grundlagen und praktische Anwendung ( $12^{\text {th }}$ ed.). Gabler, Wiesbaden.

Braunwalder, A., 2007. Energieeffizienz: Online-Beratung. Beobachter kompakt (Bauen \& Wohnen) 81 (22), 16-24.

Brosius, F., 2008. SPSS 16: das mitp-Standardwerk. Redline, Heidelberg.

Burkhalter, A., Kaenzig, J., Wüstenhagen, R., 2009. Kundenpräferenzen für leistungsrelevante Attribute von Stromprodukten. Zeitschrift für Energiewirtschaft 33 (2), 161-172.

Chapman, B., Faruqui, A., Hansen, D., Holmes, C., 2001. Hedging Exposure to Volatile Retail Electricity Prices. The Electricity Journal 14 (5), 33-38.

Clastres, C., 2011. Smart grids: Another step towards competition, energy security and climate change objectives. Energy Policy 39 (9), 5399-5408.

Curtius, H. C., Kuenzel, K., Loock, M., 2012. Generic customer segments and business models for smart grids. der markt 51 (2-3), 63-74.

COM/2011/0370, 2011. Proposal for a Directive of the European Parliament and of the Council on energy efficiency and repealing Directives 2004/8/EC and 2006/32/EC.

Darby, S., 2010. Smart metering: what potential for householder engagement? Building Research \& Information 38 (5), 442-457.

Darby, S., 2012. Metering: EU policy and implications for fuel poor households. Energy Policy 49, 98106.

Davis, F.D., 1989. Perceived Usefulness, Perceived Ease of Use, and User Acceptance of Information Technology. MIS Quarterly 13 (3), 319-340.

DeSarbo, W.S., Jedidi, K., Sinha, I., 2001. Customer Value Analysis in a Heterogeneous Market. Strategic Management Journal 22 (9), 845-857.

Dibb, S., Stern, P., Wensley, R., 2002. Marketing knowledge and the value of segmentation. Marketing Intelligence \& Planning 20 (2), 113-119.

Directive 2006/32/EC, 2006. Directive 2006/32/EC of the European parliament and of the council of 5 April 2006 on energy end-use efficiency and energy services and repealing Council Directive 93/76/EEC.

Elcom, 2010. Wie setzt sich der Strompreis zusammen? Retrieved 13 August 2010 from $<$ http://www.strompreis.elcom.admin.ch/>.

ESMA, 2008. Definition of Smart Metering and Applications and Identifications of Benefits. European Smart Metering Alliance (ESMA). Retrieved 27 Mai 2010 from <http://www.esmahome.eu/UserFiles/file/downloads/Final_reports/ESMA_WP2D3_Definition_of\%20Smart_meterin g_and_Benefits_v1_1.pdf>. 
ESMA, 2012. Smart Metering. Issues. European Smart Metering Alliance (ESMA). Retrieved 20 February 2012 from < http://www.esma-home.eu/smartMetering/issues.asp>.

European Commission, 2005. Towards Smart Power Networks (ref\# EUR 21970). Retrieved 14 April 2010 from <http://ec.europa.eu/research/energy/pdf/towards_smartpower_en.pdf>.

European Commission, 2006. European SmartGrids Technology Platform. Vision and Strategy for Europe's Electricity Networks of the Future (ref\# EUR 22040). Retrieved 14 April 2010 from <http://ec.europa.eu/research/energy/pdf/smartgrids_en.pdf>.

European Commission, 2011. The Commission's new Energy Efficiency Directive. Retrieved 20 February 2012 from <http://europa.eu/rapid/pressReleasesAction.do?reference=MEMO/11/440\&format=HTML\&aged $=0 \&$ language $=e n \&$ guilanguage $=e n>$.

EWD - Elektrizitätswerke Davos, 2010. Strompreise ab 1. Januar 2010. Retrieved 7 July 2010 from <http://www.ewd.ch/dynasite.cfm?dsmid=79413>.

Faruqui, A., Chao, H.P., Niemeyer, V., Platt, J.,Stahlkopf, K., 2001. Getting out of the dark. Regulation $24(3), 58-62$.

Faruqui, A., Mauldin, M., 2002. The barriers to real-time pricing: Separating fact from fiction. Public Utilities Fortnightly 140 (14), 30-40.

Faruqui, A., Hledik, R., Sergici, S., 2009. Piloting the Smart Grid. The Electricity Journal 22 (7), 55-69.

Faruqui, A., Harris, D., Hledik, R., 2010. Unlocking the $€ 53$ billion savings from smart meters in the EU: How increasing the adoption of dynamic tariffs could make or break the EU's smart grid investment. Energy Policy 38 (10), 6222-6231.

Faruqui, A., Sergici, S., 2010. Household response to dynamic pricing of electricity: a survey of 15 experiments. Journal of Regulatory Economics 38, 193-225.

Forsa, 2010. Erfolgsfaktoren von Smart Metering aus Verbrauchersicht. Retrieved 7 July 2010 from <http://www.vzbv.de/mediapics/smart_metering_studie_05_2010.pdf>.

Giordano, V., Fulli, G., 2012. A business case for Smart Grid technologies: A systemic perspective. Energy Policy 40 (1), 252-259.

Green, P.E., Srinivasan, V., 1990. Conjoint Analysis in Marketing: New Developments with Implications for Research and Practice. The Journal of Marketing 54 (4), 3-19.

Gustafsson, A., Herrmann, A., Huber, F., 2007. Conjoint Measurement Methods and Applications 4th ed. Springer, Berlin.

Herter, K., 2007. Residential implementation of critical-peak pricing of electricity. Energy Policy 35 (4), 2121-2130.

Holbrook, M.B. (Ed.), 1999. Consumer Value. A framework for analysis and research. Routledge, London.

Honebein, P.C., Cammarano, R.F., Donnelly, K.A., 2009. Will Smart Meters Ripen or Rot? Five First Principles for Embracing Customers as Co-Creators of Value. The Electricity Journal 22 (5), 3944.

Kim, H.-W., Chan, H.C., Gupta, S., 2007. Value-based Adoption of Mobile Internet: An empirical investigation. Decision Support Systems 43 (1), 111-126.

Kotler, P., 1997. Marketing Management: Analysis, Planning and Control. 9th edn. Prentice Hall, Upper Saddle River, NJ. 
Kranz, J., Gallenkamp, J., Picot, A.O., 2010. Exploring the Role of Control - Smart Meter Acceptance of Residential Consumers. Proceedings of the 16th American Conference on Information Systems (AMCIS) Lima (August 12-15, 2010), 1-9.

Leeds, D.J., 2009. The Smart Grid in 2010: Market Segments, Applications and Industry Players. Retrieved 12 March 2010 from <http://www.gtmresearch.com/report/smart-grid-in-2010>.

Loock, M., 2012. Going beyond best technology and lowest price: on renewable energy investors' preference for service-driven business models. Energy Policy 40, 21-27.

Louviere, J.J., Hensher, D.A., Swait, J.D., Adamowicz, W., 2003. Stated choice methods analysis and applications. Cambridge University Press, Cambridge.

Marvin, S., Chappels, H., Guy, S., 1999. Pathways of smart metering development: shaping environmental innovation. Computers, Environment and Urban Systems 23 (2), 109-126.

Miller, K.M., Hofstetter, R., Krohmer, H., Zhang, Z.J., 2011. How Should Consumers' Willingness to Pay Be Measured? An Empirical Comparison of State-of-the-Art Approaches. Journal of Marketing Research 48 (1), 172-184.

Morris, M., Schindehutte, M., Allen, J., 2005. The entrepreneur's business model: toward a unified perspective. Journal of Business Research 58 (6), 726-735.

Neenan, B., Hemphill, R.C., 2008. Societal Benefits of Smart Metering Investments. The Electricity Journal 21 (8), 32-45.

Orme, B., 2006. Getting started with conjoint analysis: strategies for product design and pricing research. Research Publishers, Madison.

Orme, B., 2010. Sample Size Issues for Conjoint Analysis. In: Orme, B. (Ed.) Getting Started with Conjoint Analysis: Strategies for Product Design and Pricing Research $2^{\text {nd }}$ ed. Research Publishers, Madison.

Parasuraman, A., 1997. Reflections on Gaining Competitive Advantage Through Customer Value. Journal of the Academy of Marketing Science 25 (2), 154-161.

Punj, G., Stewart, D.W., 1983. Cluster Analysis in Marketing Research: Review and Suggestions for Application. Journal of Marketing Research 20 (2), 134-148.

Ruiz, D.M., Castro, C.B., Armario, E.M., 2007. Explaining Market Heterogeneity in Terms of Value Perceptions. The Service Industries Journal 27 (8), 1087-1110.

Ryberg, T., 2010. Smarte Metering in Western Europe. M2M Research Series 2010. BERG INSIGHT, Gothenburg.

Sammer, K., Wüstenhagen, R., 2006. The influence of eco-labeling on consumer behavior - results of a discrete choice analysis for washing machines. Business Strategy and the Environment 15 (3), 185-199.

Sawtooth Software, 2009. The CBC/HB System for Hierarchical Bayes Estimation Version 5.0 Technical Paper. Retrieved 14 August 2010 from <http://www.sawtoothsoftware.com/education/techpap.shtml>.

Schaich, E., 1990. Schätz- und Testmethoden für Sozialwissenschaftler $\left(2^{\text {nd }}\right.$ ed. $)$. Vahlen, München.

Schira, J., 2005. Statistische Methoden der VWL und BWL - Theorie und Praxis ( $2^{\text {nd }}$ ed.). Pearson Studium, München

Schweizerischer Bundesrat, 2011. Energy Perspective 2050 - Federal Council's analysis of the options for provision of electricity. Fact Sheet. Retrieved 20 February from

<http://www.bfe.admin.ch/themen/00526/00527/index.html?lang=en\&dossier_id=05024>. 
SFOE, 2009. Smart Metering für die Schweiz - Potenziale, Erfolgsfaktoren und Massnahmen für die Steigerung der Energieeffizienz (Publ. Nr. 290085). Retrieved 3 June 2010 from $<$ http://www.bfe.admin.ch/dokumentation/energieforschung/index.html?height=400\&lang=en\&pub lication $=10248 \&$ width $=600>$.

SFOE, 2011. Grundlagen für die Energiestrategie des Bundesrates; Frühjahr 2011. Retrieved 20 February 2012 from <http://www.bfe.admin.ch/themen/00526/00527/index.html?lang=en\&dossier_id=05024>.

SFOE, 2012. Folgeabschätzung einer Einführung von «Smart Metering» im Zusammenhang mit «Smart Grids» in der Schweiz. Retrieved 20 August from <http://www.news.admin.ch/NSBSubscriber/message/attachments/27519.pdf>

Sheth, J.N., Newman, B.I., Gross, B.L., 1991. Why We Buy What We Buy: A Theory of Consumption Values. Journal of Business Research 22 (2), 159-170.

Slater, S., 1997. Developing a Customer Value-based Theory of the Firm. Journal of the Academy of Marketing Science 25 (2), 162-167.

Stromback, J., Dromacque, C., Yassin, M.H., 2011. The potential of smart meter enabled programs to increase energy and systems efficiency: a mass pilot comparison. Short name: Empower Demand. Vaasaett, Global Energy Think Tank. Retrieved 20 September 2011 from <http://www.esmig.eu/press/filestor/empower-demand-report.pdf>.

Train, K.E., 2003. Discrete Choice Methods with Simulation. Cambridge University Press, Cambridge.

Weiers, R.M., 2005. Introduction to Business Statistics (5th ed.). Thomson Brooks / Cole, Belmont.

Wertenbroch, K., Skiera, B., 2002. Measuring Consumers' Willingness to Pay at the Point of Purchase. Journal of Marketing Research 39 (2), 228-241.

Wiedmann, K.-P., Hennigs, N., Siebels, A., 2009. Value-Based Segmentation of Luxury Consumption Behavior. Psychology \& Marketing 26 (7), 625-651.

Wolsink, M., 2012. The research agenda on social acceptance of distributed generation in smart grids: Renewable as common pool resources. Renewable and Sustainable Energy Reviews 16 (1), 822-835.

Woodruff, R., 1997. Customer Value: The Next Source for Competitive Advantage. Journal of the Academy of Marketing Science 25 (2), 139-153.

Wüstenhagen, R., Wolskin, M., Bürer, M.J., 2007. Social acceptance of renewable energy innovation: An introduction to the concept. Energy Policy 35 (5), 2683-2691.

Zeithaml, V.A., 1988. Consumer Perceptions of Price, Quality, and Value: A Means-End Model and Synthesis of Evidence. The Journal of Marketing 52 (3), 2-22. 


\section{Endnotes}

1 Sawtooth Software is a standard software for designing and analyzing conjoint studies. Further information can be found under http://www.sawtoothsoftware.com/

2 Due to dummy coding the part-worth values sum up to zero. Thereby negative values do not claim the attribute to be not attractive for customers, it only states that other attributes of smart metering are preferred by customers. Further, the values cannot be compared across different attributes (Sawtooth Software, 2009).

${ }^{3}$ Our study and the experiment are of explorative nature only. This is mainly given through the still relative small sample size and the convenience we report from. Especially for the calculation of willingness-to-pay, we acknowledge that marketing scholars recently point to the necessity to combine conjoint-based approaches with additional data e.g. derived by the Becker-DeGroot-Marschak method (BDM) (Wertenbroch and Skiera, 2002; Miller et al., 2011). However, customer preferences for smart metering are an urgent topic for energy policy and for research economic reasons, we suggest that researchers rely on conjoint data, as BDM data may only hardly be collected.

4 As mentioned in endnote three, we cannot conclude that our estimation of willingness-to-pay is correct due to the explorative nature of the experiment. Furthermore, to get a realistic picture of the willingness-to-pay, other methods need to be combined with our method (Wertenbroch and Skiera, 2002; Miller et al., 2011). Thus, the here mentioned calculation solemnly exemplarily demonstrates how to combine willingness-to-pay and total costs for smart metering and how to compare them for calculating time to break even.

${ }^{5}$ We refrained from calculating the willingness-to-pay for each segment. However this can easily been done by using the formula provided in Section 4.2. 


\section{Appendix}

Total average part-worth utilities

\begin{tabular}{|c|c|c|c|}
\hline Attribute & Level & $\begin{array}{c}\text { Average } \\
\text { part-worth utilities }\end{array}$ & $\begin{array}{c}\text { Standard } \\
\text { error }\end{array}$ \\
\hline \multirow{3}{*}{ Tariff (low/high) } & $11 / 17$ Rp. per kWh & 1.24 & 0.30 \\
\hline & $8 / 30$ Rp. per kWh & 0.21 & 0.07 \\
\hline & $6 / 50$ Rp. per kWh & -1.45 & 0.32 \\
\hline \multirow[t]{3}{*}{ Base fee per month } & CHF 23.00 & 0.91 & 0.11 \\
\hline & CHF $23.00+$ CHF 2.00 & -0.19 & 0.07 \\
\hline & CHF $23.00+$ CHF 4.00 & -0.72 & 0.09 \\
\hline \multirow[t]{2}{*}{$\begin{array}{l}\text { Remote meter reading with } \\
\text { accurate monthly billing }\end{array}$} & $\begin{array}{l}\text { Yes, included in the } \\
\text { package }\end{array}$ & 0.97 & 0.08 \\
\hline & $\begin{array}{l}\text { No, not included in the } \\
\text { package }\end{array}$ & -0.97 & 0.08 \\
\hline \multirow{4}{*}{$\begin{array}{l}\text { Real-time consumption } \\
\text { feedback }\end{array}$} & Yes, via in-home display & 0.63 & 0.09 \\
\hline & Yes, via online web portal & 0.10 & 0.08 \\
\hline & Yes, via mobile device & 0.44 & 0.10 \\
\hline & $\begin{array}{l}\text { No, not included in the } \\
\text { package }\end{array}$ & -1.17 & 0.09 \\
\hline \multirow[t]{2}{*}{$\begin{array}{l}\text { Programming and steering } \\
\text { services }\end{array}$} & $\begin{array}{l}\text { Yes, included in the } \\
\text { package }\end{array}$ & 0.53 & 0.14 \\
\hline & $\begin{array}{l}\text { No, not included in the } \\
\text { package }\end{array}$ & -0.53 & 0.14 \\
\hline \multirow{2}{*}{$\begin{array}{l}\text { Home security and } \\
\text { surveillance services with } \\
\text { alert functions }\end{array}$} & $\begin{array}{l}\text { Yes, included in the } \\
\text { package }\end{array}$ & 0.38 & 0.06 \\
\hline & $\begin{array}{l}\text { No, not included in the } \\
\text { package }\end{array}$ & -0.38 & 0.06 \\
\hline
\end{tabular}

Elbow-criterion

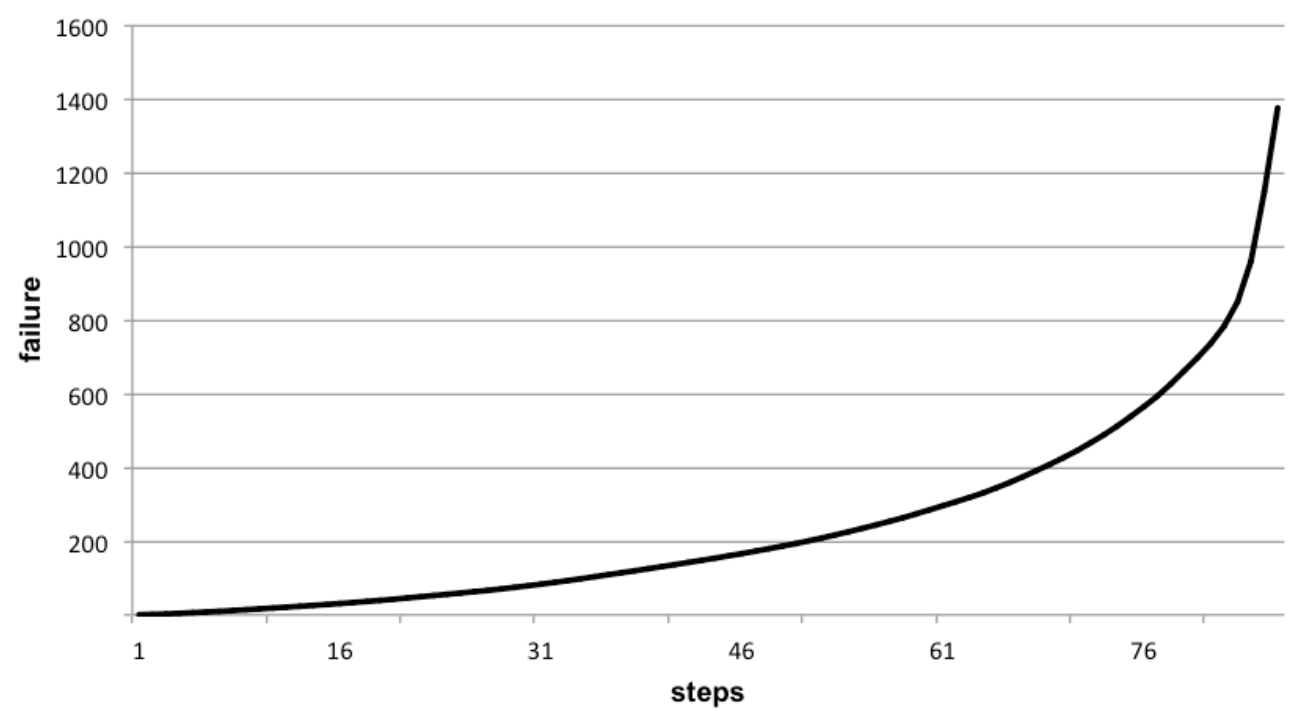


Part-worth utilities per cluster and homogeneity of the clusters

\begin{tabular}{|c|c|c|c|c|c|}
\hline Attribute & Level & $\begin{array}{c}\text { Cluster } 1 \\
\text { (homogeneity) }\end{array}$ & $\begin{array}{c}\text { Cluster } 2 \\
\text { (homogeneity) }\end{array}$ & $\begin{array}{c}\text { Cluster } 3 \\
\text { (homogeneity) }\end{array}$ & $\begin{array}{c}\text { Cluster } 4 \\
\text { (homogeneity) }\end{array}$ \\
\hline \multirow[t]{3}{*}{ Tariff (low/high) } & $\begin{array}{l}11 / 17 \text { Rp. per } \\
\text { kWh }\end{array}$ & $\begin{array}{c}4.01 \\
\left(0.601^{*}\right)\end{array}$ & $\begin{array}{c}0.26 \\
(0.327)\end{array}$ & $\begin{array}{c}-1.63 \\
(0.537)\end{array}$ & $\begin{array}{l}0.86 \\
(0.298)\end{array}$ \\
\hline & $\begin{array}{l}\text { 8/ } 30 \text { Rp. per } \\
\text { kWh }\end{array}$ & $\begin{array}{c}0.51 \\
(0.737)\end{array}$ & $\begin{array}{l}-0.15 \\
(0.570)\end{array}$ & $\begin{array}{c}0.02 \\
(0.837)\end{array}$ & $\begin{array}{c}0.49 \\
(0.655)\end{array}$ \\
\hline & $\begin{array}{l}6 / 50 \text { Rp. per } \\
\text { kWh }\end{array}$ & $\begin{array}{l}-4.51 \\
(0.382)\end{array}$ & $\begin{array}{c}-0.11 \\
(0.346)\end{array}$ & $\begin{array}{c}1.61 \\
(0.491)\end{array}$ & $\begin{array}{l}-1.34 \\
(0.457)\end{array}$ \\
\hline \multirow[t]{3}{*}{$\begin{array}{l}\text { Base fee per } \\
\text { month }\end{array}$} & CHF 23.00 & $\begin{array}{c}1.77 \\
(0.328)\end{array}$ & $\begin{array}{c}1.03 \\
(0.570)\end{array}$ & $\begin{array}{c}0.26 \\
(1.000)\end{array}$ & $\begin{array}{l}-0.22 \\
(0.316)\end{array}$ \\
\hline & $\begin{array}{l}\text { CHF } 23.00+ \\
\text { CHF } 2.00\end{array}$ & $\begin{array}{l}-0.62 \\
(0.437)\end{array}$ & $\begin{array}{c}-0.31 \\
(0.859)\end{array}$ & $\begin{array}{c}0.22 \\
(0.994)\end{array}$ & $\begin{array}{c}0.39 \\
(0.388)\end{array}$ \\
\hline & $\begin{array}{l}\text { CHF 23.00+ } \\
\text { CHF } 4.00\end{array}$ & $\begin{array}{l}-1.15 \\
(0.504) \\
\end{array}$ & $\begin{array}{c}-0.72 \\
(0.839) \\
\end{array}$ & $\begin{array}{c}-0.48 \\
(0.833) \\
\end{array}$ & $\begin{array}{c}-0.17 \\
(0.820) \\
\end{array}$ \\
\hline \multirow{2}{*}{$\begin{array}{l}\text { Remote meter } \\
\text { reading with } \\
\text { accurate monthly } \\
\text { billing }\end{array}$} & $\begin{array}{l}\text { Yes, included in } \\
\text { the package }\end{array}$ & $\begin{array}{c}0.80 \\
(0.911)\end{array}$ & $\begin{array}{c}1.44 \\
(0.589)\end{array}$ & $\begin{array}{c}1.23 \\
(0.801)\end{array}$ & $\begin{array}{c}0.33 \\
(0.373)\end{array}$ \\
\hline & $\begin{array}{l}\text { No, not included } \\
\text { in the package }\end{array}$ & $\begin{array}{l}-0.80 \\
(0.911)\end{array}$ & $\begin{array}{l}-1.44 \\
(0.589)\end{array}$ & $\begin{array}{l}-1.23 \\
(0.801)\end{array}$ & $\begin{array}{l}-0.33 \\
(0.373)\end{array}$ \\
\hline \multirow{4}{*}{$\begin{array}{l}\text { Real-time } \\
\text { consumption } \\
\text { feedback }\end{array}$} & $\begin{array}{l}\text { Yes, via in-home } \\
\text { display }\end{array}$ & $\begin{array}{c}0.78 \\
(0.991) \\
\end{array}$ & $\begin{array}{c}0.23 \\
(0.615) \\
\end{array}$ & $\begin{array}{c}0.53 \\
(0.871) \\
\end{array}$ & $\begin{array}{c}1.17 \\
(0.984) \\
\end{array}$ \\
\hline & $\begin{array}{l}\text { Yes, via online } \\
\text { web portal }\end{array}$ & $\begin{array}{c}-0.08 \\
(0.617)\end{array}$ & $\begin{array}{c}0.41 \\
(1.049)\end{array}$ & $\begin{array}{c}0.38 \\
(0.888) \\
\end{array}$ & $\begin{array}{c}-0.42 \\
(0.738)\end{array}$ \\
\hline & $\begin{array}{l}\text { Yes, via mobile } \\
\text { device }\end{array}$ & $\begin{array}{c}0.65 \\
(0.391)\end{array}$ & $\begin{array}{c}0.90 \\
(0.902)\end{array}$ & $\begin{array}{c}-0.71 \\
(0.418)\end{array}$ & $\begin{array}{c}0.57 \\
(0.925)\end{array}$ \\
\hline & $\begin{array}{l}\text { No, not included } \\
\text { in the package }\end{array}$ & $\begin{array}{l}-1.35 \\
(0.359)\end{array}$ & $\begin{array}{l}-1.53 \\
(0.450)\end{array}$ & $\begin{array}{l}-0.20 \\
(0.992)\end{array}$ & $\begin{array}{l}-1.32 \\
(0.963)\end{array}$ \\
\hline \multirow{2}{*}{$\begin{array}{l}\text { Programming } \\
\text { and steering } \\
\text { services }\end{array}$} & $\begin{array}{l}\text { Yes, included in } \\
\text { the package }\end{array}$ & $\begin{array}{l}-0.01 \\
(0.354)\end{array}$ & $\begin{array}{c}1.94 \\
(0.578)\end{array}$ & $\begin{array}{c}0.45 \\
(0.673)\end{array}$ & $\begin{array}{l}-0.76 \\
(0.212)\end{array}$ \\
\hline & $\begin{array}{l}\text { No, not included } \\
\text { in the package }\end{array}$ & $\begin{array}{c}0.01 \\
(0.354)\end{array}$ & $\begin{array}{l}-1.94 \\
(0.578)\end{array}$ & $\begin{array}{l}-0.45 \\
(0.673)\end{array}$ & $\begin{array}{c}0.76 \\
(0.212)\end{array}$ \\
\hline \multirow{2}{*}{$\begin{array}{l}\text { Home security } \\
\text { and surveillance } \\
\text { services with } \\
\text { alert functions }\end{array}$} & $\begin{array}{l}\text { Yes, included in } \\
\text { the package }\end{array}$ & $\begin{array}{c}0.04 \\
(0.210)\end{array}$ & $\begin{array}{c}0.36 \\
(0.569)\end{array}$ & $\begin{array}{c}0.44 \\
(0.992)\end{array}$ & $\begin{array}{c}1.27 \\
(0.944)\end{array}$ \\
\hline & $\begin{array}{l}\text { No, not included } \\
\text { in the package }\end{array}$ & $\begin{array}{l}-0.04 \\
(0.210)\end{array}$ & $\begin{array}{l}-0.36 \\
(0.569)\end{array}$ & $\begin{array}{l}-0.44 \\
(0.992)\end{array}$ & $\begin{array}{l}-1.27 \\
(0.944)\end{array}$ \\
\hline
\end{tabular}

